\title{
PREFACE AND ACKNOWLEDGMENTS
}

\author{
The Humanities are that form of knowledge in which the knower \\ is revealed. All knowledge becomes humanistic when this effect \\ takes place, when we contemplate not only a proposition but \\ also the proposer, when we hear the human voice behind what \\ is being said.
}

Charles Frankel, "Why the Humanities?"

ACLS Newsletter 30 (1979): 15-16

This project dates back to the summer of 1992, when I began reading M. M. Bakhtin's Art and Answerability, then newly translated. Having earlier read his Problems of Dostoevsky's Poetics and Rabelais and His World, standard fare for any self-respecting academic in the humanities in the 1980s, I was entirely unprepared for Bakhtin's long essay "Author and Hero in Aesthetic Activity," which is overtly metaphysical in orientation and soaked through with religious rhetoric and sentiment. This essay seemed to be diametrically opposed to the standard view of what Bakhtin was all about, and unless one chose to dismiss it as a piece of juvenilia, it had to be taken on board as evidence of a profound, unresolved, and-to me-intriguing ambivalence in Bakhtin's thought. Having read and reread the essay throughout that summer and in the following years, I have come to believe that the fault line, so clearly visible between "Author and Hero" and Problems of Dostoevsky's Poetics, ought to be acknowledged and negotiated through a broader perspective; that Bakhtin's philosophical quest is closely related to what is currently labeled "continental," but perhaps—as Richard Rorty suggests—should more aptly be designated "conversational" philosophy; and that the strength of Bakhtin's work lies, not in its neat dovetailing with postmodernist buzzwords, but in its self-conscious threshold position.

This study will, therefore, eschew the routine assertions of the crisis, or the downright demise of the subject, which all too often become 
mere rhetorical tokens in discussions of postmodernity, along with pronouncements of the "death of the author." In the case of Bakhtin, the question of the subject is not only historically and concretely relevant but also acutely personal, inasmuch as Bakhtin-the real person writing under the long shadow of political state terrorism, enforced exile, physical pain, and material deprivation-must have experienced his own position as a "subject in process" (in the French juridical sense of being on trial as well), and the ethical question "How to be?" as bloodchillingly literal and urgent. The radical chic of dispensing with the notion of agency and responsibility and of stripping the subject of all powers of resistance would have been a disempowering, self-defeating gesture that he and his associates could hardly afford.

The author is not quite dead, then. And if he seems to be naïve at times, this is not the sheltered naïveté of the historically privileged West. Where the personal stakes are so high, and questions of how to be become very real—nonacademic, one might say — and have to be acted upon, there is an added gravitas that invites the reader to do some honest thinking. And so, while this is not a biographical study in any conventional sense, it is nonetheless produced with a powerful sense of Bakhtin, the speaker, revealing himself. And what he has to say on the question of ethics and subjectivity deserves to be listened to.

As indicated above, this book took many years to mature, but it could not have been otherwise. As the years went by, the writing became a spiraling process: whenever I went back to a section I thought long completed and done with, I discovered that there was actually a lot more, or a lot else, to be said at that point, and thus often found myself beginning anew, taking on board what I had learned or unlearned in the meantime. Not the best way to get to the end of any project, for sure, but perhaps not the worst either.

If I had to find some justification for this long process of maturation, I would cite Lionel Trilling's profound discovery that the nature of the reader's engagement with certain texts is that of being read by them. "I have been read," he wrote in his essay on teaching the modernists, "by Eliot's poems and by Ulysses and by Remembrance of Things Past and by The Castle for a good many years now, since early youth. Some 
of these books at first rejected me; I bored them. But as I grew older and they knew me better, they came to have more sympathy with me and to understand my hidden meanings. Their nature is such that our relationship has been very intimate" ("On the Teaching of Modern Literature," 7). I believe that this insight may be extended to the nature of Bakhtin's work, whose very open-endedness invites the reader to evolve within an ongoing conversation. Perhaps, then, the intimacy of the relationship is a good enough justification of the time taken to be understood by the text.

The reading and rereading I needed to do in order to outgrow earlier conceptions of the project and to take it in different directions would not have been possible without the material support of the Research Authority staff at the University of Haifa, who have invariably been helpful and kind; a generous research grant from the Israel Science Foundation (ISF); and a research fellowship granted by the Center for Advanced Studies (CAS) in Oslo, Norway, where I spent some of the best months of my working life as a member of an international research team on Modernism and Narrative Theory. These months produced three collections of essays and some lifelong friendships. I would, therefore, like to acknowledge the assistance of these institutions with much gratitude and, on a more personal note, to thank my friends at CAS, Anniken Greve, Jeremy Hawthorn, Jakob Lothe, J. Hillis Miller, Jim Phelan, Susan Rubin Suleiman, Beatrice Sandberg, Annette Storeide, and Anne Thelle, for having been there to share ideas and feelings, to talk and listen to. As readers of Bakhtin know, human discourse is always implicitly addressed to an interlocutor, present or absent, nearby or far off. This is, of course, also true of academic conversations, and I would like to acknowledge my indebtedness to four of my implicit interlocutors-Michael Gardiner, Ken Hirschkop, Michael Holquist, and Sue Vice-for the articulated and unarticulated dialogues we held over these years and for their unfailing friendly and generous support. As the project came to its conclusion, I had the enormous benefit of assistance from Sergeiy Sandler, a young scholar of truly encyclopedic knowledge, who did his best to keep me on the straight and narrow with respect to Russian sources and translated some of Bakhtin's lesser-known texts for this book. I am very grateful to Professor Sergeiy Bocharov, Bakhtin's disciple and the 
literary executor of his estate, who has kindly given me permission to have these texts translated and to quote them. And, almost needless to say, I would also like to express my deepest gratitude to Jim Phelan, Anthony Steinbock, Meir Sternberg, Leona Toker, and other editors of academic journals where some of the work that makes up this volume was initially formulated and given voice.

Most and first of all, I am indebted to my lifelong partner, Achick, and to my children, Maya and Yonnie, for their sometimes amused but always fond tolerance of my philosophical obsessions, for the joy of being together, and for the generosity of their love, which is the very bedrock of my life. 